\title{
Natural history of the lizard Enyalius iheringii (Squamata, Leiosauridae) in southern Brazilian Atlantic forest
}

\author{
Ricardo Rautenberg ${ }^{1} \&$ Rudi R. Laps ${ }^{2}$ \\ 1. Departamento de Ciências Naturais, Universidade Regional de Blumenau, Rua Antônio da Veiga, 140, 89012-500 Blumenau, SC, Brazil. \\ (ricardo_herpeto@yahoo.com.br) \\ 2. Departamento de Biologia, Universidade Federal de Mato Grosso do Sul, 79070-900 Campo Grande, MS, Brazil. (rudilaps@uol.com.br)
}

\begin{abstract}
Studies on the natural history of the lizard Enyalius iheringii Boulenger, 1885, as well as other tropical lizards, are rare. In this study, some aspects of the natural history of this endemic species from the Atlantic forest are reported in areas of Vale do Itajaí, state of Santa Catarina, Brazil. Twenty individuals were found, of which 18 were collected. Most of them were found over the vegetation $(n=17)$ and on the ground $(n=3)$. The main defensive strategy displayed was camouflage $(n=16)$. Jumping ( $n=1)$, jumping and running $(n=1)$ and running $(n=2)$ were also observed in some individuals. When handled, lizards exhibited mouth wide open, hissing, and occasionally biting, as well as color change in males. Regarding its diet, the numerically most important prey was beetles (Coleoptera), followed by Lepidoptera larvae. Beetles, lepidopteran larvae and spiders were the most frequent food items. Males and females did not differ in size. Three sexually mature females (100-113 mm SVL) were found in December and January.
\end{abstract}

KEYWORDS. Diet, reproduction, defensive behavior, microhabitat use.

RESUMO. História natural do lagarto Enyalius iheringii (Squamata, Leiosauridae) no sul da Mata Atlântica. Informações sobre a história natural do lagarto Enyalius iheringii Boulenger, 1885 são escassas, assim como para várias espécies de lagartos de florestas tropicais. Neste estudo abordamos vários aspectos da história natural desta espécie endêmica da Mata Atlântica, na região do Vale do Itajaí, Santa Catarina. Encontramos 20 indivíduos, dos quais 18 foram coletados. A maioria foi encontrada sobre a vegetação $(\mathrm{n}=17)$ e o restante sobre o solo $(\mathrm{n}=3)$. A camuflagem foi a principal tática defensiva utilizada $(\mathrm{n}=16)$, apesar de também observarmos salto $(\mathrm{n}=1)$, salto e corrida $(n=1)$ e corrida $(n=2)$. Quando manipulados, apresentaram o comportamento de escancarar a boca, emissão de silvos e eventualmente mordidas, assim como mudança de coloração em machos. Com relação à dieta, as presas mais consumidas foram coleópteros, seguidos por larvas de lepidópteros; em relação à frequência, os itens mais representativos foram coleópteros, seguidos por larvas de lepidópteros e aranhas. Machos e fêmeas não diferiram em relação ao tamanho do corpo. Três fêmeas reprodutivas (100-113 mm CRC) foram encontradas nos meses de dezembro e janeiro.

PALAVRAS-CHAVE. Dieta, reprodução, comportamento defensivo, uso do microhábitat.

Although there is a great number of endemic species of reptiles in the Brazilian Atlantic forest, some basic aspects of this group are still unknown (MARQUES \& SAZIMA, 2004). The majority of lizard species of the genus Enyalius Wied, 1821 are endemic to the Atlantic forest (ETHERIDGE, 1969; JACKSON, 1978), but little is known about their ecology (VAN SLUYs et al., 2004). This is probably due to the difficulty in the observation of lizards in tropical forests because of the high vegetation density, the great leaf litter production, and the fact that some species are active only in the darkest environments or display cryptic habits that makes this group hard to study (Duellman, 1987). Moreover, the capture of tropical reptiles in general is difficult because of its low density (MANGinI \& Nicola, 2003) and some lizards are hard to see because of their coloration, which is similar to the vegetation, including Enyalius iheringii Boulenger, 1885 (SAZIMA, 1994; Lema, 2002).

Biological information about species of the genus Enyalius exists for E. iheringii (JACKSON, 1978; SAZIMA \& Haddad, 1992; Lema, 1994, 2002; Marques \& Sazima, 2004), E. catenatus (Wied, 1821) (VAnzolini, 1972), E. leechii (Boulenger, 1885) (VIтT et al., 1996;), E. bilineatus Duméril \& Bibron, 1837 (VANZOLINI, 1972; JACKSON, 1978; ZAMPROGNo et al., 2001), E. perditus Jackson, 1978 (SousA et al., 2000; Lima \& Sousa, 2006; Sousa \& CRUZ, 2008) and E. brasiliensis (Lesson, 1828) (JACKSON, 1978; LEMA, 1994, 2002; VAN SLuYs et al., 2004). Studies focusing on systematics and geographic distribution of Enyalius are those of ETHERIDGE (1969), JACKSON (1978) and RodRIGUES et al. (2006). Recently the cytogenetics of the genus was studied (BerTolotto et al., 2002). Moreover, there are recent studies of the helminth parasites of these lizards (Sousa et al., 2007; VRCiBradic et al., 2007).

Enyalius iheringii is endemic to the Brazilian Atlantic forest (ETHERIDGE, 1969; JACKSON, 1978; BÉRNILS, 2003), one of the most threatened ecosystems of the world (WILSON, 1988). Little information on the ecology of species is available, and existing data is fragmented in book chapters (SAZIMA \& HADDAD, 1992; Lema, 2002; Marques \& SAZIMA, 2004) or short citations in scientific papers (JACKSON, 1978; LEMA, 1994).

In this study we present natural history information on E. iheringii in the southern Brazilian Atlantic forest, including data on its diet, breeding, microhabitat use and behavior.

\section{MATERIAL AND METHODS}

The lizards were collected manually in monthly surveys, using visual search in the mornings and evenings, usually between 08:00 $\mathrm{h}$ and 16:00 $\mathrm{h}$, from February 2004 to March 2005, with an average of three samplings per month, in areas of dense secondary forest in the Vale do Itajaí, Santa Catarina, Brazil. Most sampling was done in the municipality of Blumenau $(n=16)$, but 
one individual was collected in Brusque and another in Ilhota, sites located less than $30 \mathrm{~km}$ from Blumenau.

The snout-vent length (SVL) was measured with a $0.1 \mathrm{~mm}$ precision caliper. The animals were killed with ether soon after their capture in the field, following MouRALEITE et al. (1993). The lizards (nine males and nine females) were fixed in formol $10 \%$, preserved in alcohol $70 \%$, dissected and deposited in the collection of Laboratório de Zoologia e Taxidermia at Universidade Regional de Blumenau (on the numbers FURB 2842, 2992, 2993, 11001-11005, 11012-11016, 11027, 11029-11031, 11058).

The diet was inferred from stomach content, analyzed in a stereomicroscopic. The content was identified up to level of order, and the numeric and relative frequencies were calculated. To analyze the volume, only preys found intact were considered, according to ZAMPRogno \& TeIXeIra (1998) and ZAMPRogno et al. (2001). The lenght and width of prey were measured with a caliper, and the volume was estimated using a modified equation spheroid: volume $=4 / 3 \pi($ length $/ 2) \times(\text { width } / 2)^{2}$ (VITT et al., 1996).

Specimens larger than $60 \mathrm{~mm}$ were considered adults (following VAN SLUYS et al., 2004). Female reproductive status was determined by the presence of vitellogenic follicles and/or of eggs in oviduct, according to VAN SLUYS et al. (2004).

The microhabitat where the lizards were found was classified into four categories: ground over leaf litter, leaves or tree branches, tree trunks, and tree fissures. The escape and defense behaviors exhibited by the individuals during the capture trials were observed and registered.

\section{RESULTS}

The stomach content of 18 individuals of Enyalius iheringii revealed 56 items belonging to 10 arthropod orders, besides plant fragments and scales (Tab. I). The most numerous items were beetles $(28.5 \%)$ and lepidopterous larvae $(25 \%)$. The most frequently consumed items were beetles $(66.7 \%)$, lepidopterous larvae $(44.4 \%)$ and spiders $(38.9 \%)$.

The width of intact preys varied from 0.5 to $6.4 \mathrm{~mm}$ (mean=5.71 $\pm 1.77 ; n=9)$ and the length from 9.2 to 57.6 $\mathrm{mm}($ mean $=31.14 \pm 17.79 ; \mathrm{n}=9)$. No significant relationship

Table I. Diet composition of Enyalius iheringii Boulenger, 1835 in Vale do Itajaí, Santa Catarina, Brazil. Frequency (\%), number of stomach with the prey item and its percentage; $\mathrm{n}(\%)$, total prey number and percentage.

\begin{tabular}{lcc}
\hline Item & Frequency $(\%)$ & $\mathrm{n}(\%)$ \\
\hline Coleoptera & $12(66.7)$ & $16(28.5)$ \\
Lepidoptera (larvae) & $8(44.4)$ & $14(25)$ \\
Araneae & $7(38.9)$ & $8(14.3)$ \\
Isopoda & $4(22.2)$ & $5(8.9)$ \\
Hymenoptera & $3(16.7)$ & $4(7.1)$ \\
Orthoptera & $2(11.1)$ & $2(3.6)$ \\
Lepidoptera (adult) & $1(5.5)$ & $2(3.6)$ \\
Homoptera (nymph) & $1(5.5)$ & $2(3.6)$ \\
Opiliones & $1(5.5)$ & $1(1.8)$ \\
Blattaria & $1(5.5)$ & $1(1.8)$ \\
Trichoptera & $1(5.5)$ & $1(1.8)$ \\
Plants & $4(22.2)$ & \\
Scales & $3(16.7)$ & \\
Total & & 56 \\
\hline
\end{tabular}

was found between prey volume and lizard size $(\mathrm{r}=0.19$; $\mathrm{F}_{1,6}=1.41 ; \mathrm{p}=0.27 ; \mathrm{n}=9$ ).

Male's size ranged from 83 to $98.7 \mathrm{~mm}$ (SVL) $(m e a n=90.7 \pm 5.9 \mathrm{~mm} ; \mathrm{n}=9)$ and female size varied from 48.1 to $113 \mathrm{~mm}$ (SVL) $($ mean=82.6 $\pm 32.2 \mathrm{~mm}$; $=9)$. The average size of adults ranged from 60.9 to $113 \mathrm{~mm}$ (SVL) (mean=92 $\pm 15.5 \mathrm{~mm} ; \mathrm{n}=7$ ). Considering only adults, no significant difference was found between males and females SVL ( $t$ test: $t=-0.228 ; \mathrm{gf}=15 ; \mathrm{p}=0.823$ ).

Three females in reproductive condition were collected, two of which with well developed vitellogenic follicles ( $n=11$ and $n=17)$ and another with eggs in the oviduct $(n=12)$. The smallest reproductive female had SVL $100 \mathrm{~mm}$. Reproductive females were found in December and January.

The two smaller reproductive females $(\mathrm{SVL}=100$ and SVL=105 mm) showed 11 well developed vitellogenic follicles and 12 eggs in the oviduct, respectively, while the larger reproductive female $(\mathrm{SVL}=113 \mathrm{~mm})$ showed 17 well developed vitellogenic follicles. Although the larger reproductive female had the larger clutch size, there was no evidence of a relationship between the size of the clutch and the size of the female.

Three out of 20 lizards observed were found on forest floor, and the remaining in trunks, twigs, or over leaves of trees and shrubs. The microhabitats used were branches and tree leaves $(70 \%)$, ground litter $(15 \%)$, tree trunks $(10 \%)$ and trunk crevices $(5 \%)$.

The camouflage seems to be the main defense strategy of Enyalius iheringii, since 16 out of 20 lizards found remained still upon approach for capture. One juvenile discovered over a leaf suddenly jumped to another leaf upon perceiving our approach and another individual flushed into a hole at a tree base, showing that escape behavior can be used by this species, even with low frequency.

Other two lizards observed ran away before capture. One of them was on the forest floor and ran when approached; the other stood on a tree trunk and jumped to the ground, running as well. The two lizards gave a short run, followed by immobility, repeating this behavior as the persecution went on, until they were out of sight. Moreover, the lizards emitted a weak short whistle, noticeable only with the individual close to the head of the observer. Some male lizards showed a brown coloration, which changed to olive-green within a few minutes after capture.

Enyalius iheringii was found both in continuous Atlantic forest and in fragmented areas. It was verified that this species can occupy both forest interior $(n=18)$ and forest edges $(n=2)$. But it was not found any tendency, since the individuals recorded in the forest edge were found fortuitously when we got into the study areas, not being systematically registered.

\section{DISCUSSION}

Regarding to the diet, our study differs numerically from the results found for other species of the genus Enyalius, for which the most important items were hymenopterans, isopterans, isopods and orthopterans (VITT et al., 1996; Zamprogno et al., 2001; VAn Sluys et al., 2004; TEIXEIRA et al., 2005).

As to the most frequent items in the diet, $E$. iheringii is more similar to E. brasiliensis (VAN SLUYS et al., 2004), inasmuch as larvae constitute a large portion of diet, but differs in the high frequency of coleopterans, 
as found in our study. However, the diet of E. brasiliensis seems variable, since TEIXEIRA et al. (2005) found Blattaria as the more frequent item in the species' diet. However, the results differed when compared with other studies the diet composition of $E$. bilineatus, where orthopterans (ZAMProgno et $a l ., 2001$ ) and hymenopterans (TEIXEIRA et al., 2005) were the most frequent items. MARQUES \& SAZIMA (2004) analyzed the diet of E. iheringii $(n=3)$ and found spiders, lepidopteran larvae and adult beetles (also observed in our study), besides coleopteran larvae and flying individuals of Isoptera, all of which are prey items that were not recorded by us. We found one individual of Trichoptera, item not found in other studies. Flying individuals of both Isoptera and Trichoptera represent the dispersion and reproductive phase of these insects, occurring sporadically, what may explain its occasional presence as a prey item in the genus Enyalius.

For E. bilineatus the prey width ranges from 1.1 to 5.3 $\mathrm{mm}$ (average $=2.4$ ) and the length from 2.1 to $28.2 \mathrm{~mm}$ (average=9.1) (ZAMPROGNO et al., 2001). For E. perditus the length ranged from 1.25 to $32.3 \mathrm{~mm}$ (SousA \& CRUZ, 2008). It was found no significant relationship between the prey volume and the lizard size for E. iheringii, as well as for others species of the genus Enyalius (ZAMPROGNO et al., 2001; VAN SLuYs et al., 2004; TEIXEIRA et al., 2005).

The skin pieces found on stomach were reported for other species of Enyalius (VANZOLINI, 1972; VITT et al., 1996; Sousa et al., 2000; VAN SLuYs et al., 2004; TEIXEIRA et al., 2005). Moreover, observing the molt process in E. perditus, Sousa et al. (2000) verified that once the skin was molted in many pieces, the lizard immediately swallowed it. Although it was not possible to identify the scales found in the stomach content of $E$. iheringii, probably they are a result of its own molt.

The presence of plant fragments in stomach content of some individuals was recorded for other Enyalius species also (ZAMPRogno et al., 2001; VAN SLuYs et al., 2004). Considering the low frequency of vegetal material found in these studies, we believe that the ingestion of plants by Enyalius lizards can be considered accidental, swallowing together with the prey item.

Notwithstanding it was not recorded soil preys (e. g., Oligochaeta, Diplopoda) as recorded for others species of the genus Enyalius (VAnzolini, 1972; ZAMPROGNO et al., 2001; VAN SLUYS et al., 2004), but we observed three $E$. iheringii individuals in activity on the ground. Moreover, SAZIMA \& HADDAD (1992) recorded one E. iheringii over the ground preying on Orthoptera, what indicates that this species can forage in the soil as well as on the vegetation. The same behavior was observed for E. bilineatus (ZAMPROGNO et al., 2001).

Enyalius iheringii can be considered a sit-andwait predator: besides a generalist diet, it also has a cryptic coloration, low mobility and a large clutch size, which are typical characteristics of lizards which have this foraging mode (Huey \& PianKa, 1981; Silva \& AraúJo, 2008). The same behavior was observed for E. bilineatus (ZAMPROGNO et al., 2001). According to SouZA \& CRUZ (2008), females of $E$. perditus show a foraging mode similar to sit-andwait predators, and males show a foraging mode similar to active foragers. According to BUTLER (2005) and SILVA \& ARAúJo (2008), there are intermediate categories in relation to these two foraging modes.

In relation to the reproduction, our data about the clutch size looks like the data existing for this species $(n=10)$
(MARques \& SAZIMA, 2004) and for other species of Enyalius such as E. leechii (n=10 and $\mathrm{n}=14)$ (VITT et al., 1996), E. brasiliensis $(\mathrm{n}=10$ and $\mathrm{n}=5)(\mathrm{VAN}$ SLUYS et al., 2004) and $(\mathrm{n}=8$ and $\mathrm{n}=14)$ (TEIXEIRA et al., 2005). For E. bilineatus the clutch size ranged from $\mathrm{n}=2$ to $\mathrm{n}=6$ (TEIXEIRA et al., 2005). The clutch size found for one female $(n=17)$ in our study differed from other species cited, and it was more similar to E. catenatus data, with a clutch of 18 eggs (GRANTSAU, 1966). The number of eggs for species of genus Enyalius is rather variable, since was observed that for one laying, there were two eggs for E. catenatus (VANZOLINI, 1972) and another one 18 eggs (GRANTSAU, 1966).

The size of smaller reproductive female for $E$. iheringii was similar to these recorded for E. leechii $(\mathrm{SVL}=100 \mathrm{~mm})$ (VITT et al., 1996) and E. brasiliensis (SVL=92.4 mm) (VAN SLUYs et al., 2004) and (SVL=89.9 mm) (TEIXEIRA et al., 2005). The smaller reproductive female founded for $E$. bilineatus was SVL=66.7 mm (TeIXEIRA et al., 2005).

As well as in our study with E. iheringii, VAN SLUYS et al. (2004) also found no significant difference between males and females for E. brasiliensis. However, TEIXEIRA et al. (2005) observed that E. brasiliensis females are significantly larger than males, result also obtained for $E$. bilineatus.

We observed that the average size of females is larger than the average size of males, which was also noticed in other species of the genus Enyalius (JACKSON, 1978; VITT et al., 1996; VAN SLuYs et al., 2004). Although we not observed any relation between the clutch size and the size of the female, for $E$. brasiliensis and E. bilineatus this relation was found (TEIXEIRA et al., 2005), suggesting that there is a tendency for selection of larger females for species of Enyalius. Based on this, a larger sample may show differences in body size between males and females, with a tendency to larger females in E. iheringii.

The reproductive females recorded in December and January in our study, and by MARques \& SAzima (2004) in February suggests that some reproductive seasonality is present for E. iheringii. Other Enyalius species presents reproductive seasonality, as $E$. brasiliensis reproducing from November to January (VAN SLuYs et al., 2004), and E. leechii with reproductive activity between December and March (VITT et al., 1996). Moreover, we collected the smaller individuals (two females with 48.1 and $51.1 \mathrm{~mm}$ ) in January. VAN SLUYS et al. (2004) found the smaller E. brasiliensis individuals in summer (January and March). For E. bilineatus the majority of young and females with eggs in the oviduct was recorded in October-December, but one female with eggs in oviduct found in May and two young in June, suggesting that in this species the reproductive activity can be extended or continuous, or two reproductive events yearly (TEIXEIRA et al., 2005). According with VITT (1990), the majority of sedentary foragers showed reproductive seasonality, while the active foragers reproduced continuously.

In relation to the microhabitat use, we found $E$. iheringii mainly in arboreal habitats. According to SAZIMA \& HADDAD (1992), E. iheringii is active during the day and found on vegetation as well as in the ground, and sleeps roosted in branches at night. In our study one individual was found in a crevice on a trunk, behavior that was recorded for Enyalius brasiliensis (VAN SLUYS et al., 2004). Moreover, Tortato \& CAMPBEll-Thompson (2006) recorded use of nest-boxes as shelter by one individual 
of E. iheringii. According to gathered data, we believe that $E$. iheringii can use shelters (as crevices and holes) during activity period when these refuges are available.

In relation to the defensive behavior, we observed camouflage, jumping and running, common behaviors in sedentary lizards (HuEy \& PIANKA, 1981). When handled, the lizards opened their mouth wide and eventually bite off, as observed by MARQUES \& SAZIMA (2004).

In some males we observed a change in coloration within few minutes after capture. Change in coloration was observed also by GranTSAu (1966) in males of $E$. catenatus, in this case associated to change of activity and resting periods. For $E$. perditus a change in color in males was observed during coitus (Lima \& SousA, 2006).

New studies are necessary to increase the knowledge of the biology of this species, as well as other species of the genus Enyalius. We would like to emphasize the importance of conservation of Atlantic forest areas, both continuous and fragmented, which protects many endemic species, such as Enyalius iheringii.

Acknowledgments. The authors would like to express gratitude to André F. B. Lima (UFRGS), Júlio C. de Moura-Leite (MHNCI/PUCPR) and Laura Verrastro (UFRGS) for the suggestions and bibliographical material provided for this study. To Renato $\mathrm{S}$. Bérnils (MNRJ) for the critical review of the manuscript. To Instituto Parque das Nascentes, Fundação Municipal do Meio Ambiente de Blumenau and IBAMA-SC for the visiting and collecting authorizations. To Melissa A. Santos and Andréa Kramer for the text translation. This article is a result of the Bachelor's degree dissertation of the first author.

\section{REFERENCES}

BéRnils, R. S. 2003. Répteis da Floresta Atlântica. In: Fernandes, C. R. ed. Floresta Atlântica - Reserva da Biosfera. Curitiba, C. R. Fernandes. p.150-173.

Bertolotto, C. E. V.; Pellegrino, K. C. M.; Rodrigues, M. T. \& Yononega-Yassuda, Y. 2002. Comparative cytogenetics and supernumerary chromosomes in the Brazilian lizard genus Enyalius (Squamata, Polychrotidae). Hereditas 136(1):51-57.

Butler, M. A. 2005. Foraging mode of the chameleon, Bradypodion pumilum: a challenge to the sit-and-wait versus active forager paradigm? Biological Journal of the Linnean Society 84:797-808.

Duellman, W. E. 1987. Lizards in an Amazonian rain forest community: resource, utilization and abundance. National Geographic Research 3(4):489-500.

EtheridGE, R. 1969. A review of the iguanid lizard genus Enyalius. Bulletin of British Museum of Zoology 18(8):231-260.

Grantsau, R. 1966. Enyalius catenatus, das Brasilianische "Cameleon". Aquarium und Terrarium Zeitschrift 19(7):217-219

Huey, R. B. \& PianKa, E. R. 1981. Ecological consequences of foraging mode. Ecology 62(4):991-999.

JACKSON, J. F. 1978. Differentiation in the genera Enyalius and Strobilurus (Iguanidae): implications for Pleistocene climatic changes in eastern Brazil. Arquivos de Zoologia 30(1):1-79.

Lema, T. 1994. Lista comentada dos répteis ocorrentes no Rio Grande do Sul, Brasil. Comunicacões do Museu de Ciências e Tecnologia da PUCRS, Série Zoologia, 7:41-150. 2002. Os répteis do Rio Grande do Sul. Porto Alegre, PUCRS. 220p.

Lima, A. F. B. \& Sousa, B. M. 2006. Court and copulation behaviors of Enyalius perditus Jackson, 1978 (Squamata, Leiosauridae) in captivity conditions. Revista Brasileira de Zoociências 8(2):193-197.

Mangini, P. R. \& Nicola, P. A. 2003. Captura e marcação de animais silvestres. In: Cullen JR., L.; RudRAN, R. \& VAlLADARESPádua, C. eds. Métodos de estudos em biologia da conservacão e manejo da vida silvestre. Curitiba, UFPR. p.91-124.

Marques, O. A. V. \& Sazima, I. 2004. História natural dos répteis da Estação Ecológica Juréia-Itatins. In: Marques, O. A. V. \& Duleba, W. eds. História natural da Estação Ecológica Juréia-Itatins. Ribeirão Preto, Holos. p. 257-277.

Moura-Leite, J. C.; Bérnils, R. S. \& Morato, S. A. A. 1993. Método para a caracterização da herpetofauna em estudos ambientais. In: SUDERHSA (Superintendência dos Recursos Hídricos e Meio Ambiente do Paraná) ed. MAIA: Manual de Avaliação de Impactos Ambientais. Curitiba, AIP/GTZ. p. 1-5.

Rodrigues, M. T.; Freitas, M. A.; Silva, T. F. S. \& Bertolotto, C. E. V. 2006. A new species of lizard genus Enyalius (Squamata, Leiosauridae) from the highlands of Chapada Diamantina, state of Bahia, Brazil, with a key to species. Phyllomedusa $\mathbf{5}(1): 11-24$

SAZIMA, I. 1994. Répteis. In: FCPPFESP (Fundação para a Conservação a Produção Florestal do Estado de São Paulo) ed. Intervales. São Paulo, FCPFESP. p.48-157.

Sazima, I. \& Haddad, C. F. B. 1992. Répteis da Serra do Japi: notas sobre história natural. In: Morellato, L. P. C. org. História natural da Serra do Japi - ecologia e preservação de uma área florestal no sudeste do Brasil. Campinas, Unicamp. p.212-236.

Silva, V. N. \& Araúuo, A. F. B. 2008. Ecologia dos lagartos brasileiros. Rio de Janeiro, Technical Books. 271p.

Sousa, B. M. \& Cruz, C. A. G. 2008. Hábitos alimentares de Enyalius perditus (Squamata, Leiosauridae) no Parque Estadual Ibitipoca, Minas Gerais, Brasil. Iheringia, Série Zoologia, 98(2):260-265.

Sousa, B. M.; Cruz, C. A. G.; Carvalho, R. M. H. \& Silva, M. N. 2000. Descrição do processo de muda em Enyalius perditus Jackson (Reptilia, Sauria, Polychrotidae). Revista Brasileira de Zoologia 17(1):225-228

Sousa, B. M.; Oliveira, A. \& Lima, S. S. 2007. Gastrointestinal helminth fauna of Enyalius perditus (Reptilia: Leiosauridae): relation to host age and sex. The Journal of Parasitology 93(1):211-213.

Teixeira, R. L; Roldi, K. \& VRcibradic, D. 2005. Ecological comparisons between the sympatric lizards Enyalius bilineatus and Enyalius brasiliensis (Iguanidae, Leiosaurinae) from an Atlantic Rain-Forest area in southeastern Brazil. Journal of Herpetology 39(3):504-509.

Tortato, M. A. \& CAmpbell-Thompson, E. R. 2006. Ocupação de caixas de nidificacão por vertebrados de pequeno porte em área de Floresta Atlântica no sul do Brasil, e sua viabilidade de uso. Biotemas 19(2):67-75.

Van Sluys, M.; Ferreira, V. M. \& Rocha, C. F. D. 2004. Natural history of the lizard Enyalius brasiliensis (Lesson, 1828) (Leiosauridae) from an Atlantic Forest of southeastern Brazil. Brazilian Journal of Biology 64(2):353-356.

VANZolini, P. E. 1972. Miscellaneous notes on the ecology of some Brazilian lizards (Sauria). Papéis Avulsos de Zoologia 26(8):83-115

VitT, L. J. 1990. The influence of foraging mode and phylogeny on seasonality of tropical lizard reproduction. Papéis Avulsos de Zoologia 37(6):107-123

VitT, L. J.; Ávila-Pires, T. C. S. \& ZANI, P. A. 1996. Observations on the ecology of the rare Amazonian lizard, Enyalius leechii (Polychrotidae). Herpetological Natural History 4(1):77-82.

Vrcibradic, D.; Vicente, J. J. \& Bursey, C. R. 2007. Helminths infecting the lizard Enyalius bilineatus (Iguanidae; Leiosaurinae) from an Atlantic Rainforest area in Espirito Santo state, southeastern Brazil. Amphibia-Reptilia 28(1): 166-169.

Wilson, E. O. 1988. Biodiversity. Washington, National Academy of Sciences. 658p.

Zamprogno, C. \& Teixeira, R. L. 1998. Hábitos alimentares da lagartixa-de-parede Hemidactylus mabouia (Reptilia, Gekkonidae) da planície litorânea do norte do Espírito Santo, Brasil. Revista Brasileira de Biologia 58(1):143-150.

Zamprogno, C.; Zamprogno, M. G. F. \& Teixeira, R. L. 2001 Evidence of terrestrial feeding in the arboreal lizard Enyalius bilineatus (Sauria, Polychrotidae) of southeastern Brazil. Revista Brasileira de Biologia 61(1):91-94.

Recebido em julho de 2008. Aceito em dezembro de 2010. ISSN 0073-4721

Artigo disponível em: www.scielo.br/isz

Impresso e distribuído em 2011. 